the various chapters and the various chapters are required to make progress reports each three months to the Board of Directors so that a full and comprehensive report will be ready for the next annual convention for its consideration. The President is directed to use the influence of his office to the end that such investigation is promptly begun and diligently prosecuted and results of such investigation given proper publicity for the common interest of the profession and public.

During the year six formal cases, Nos. 13, $14,15,16,17$ and 19 , were considered by your committee and approved by the Board of Directors and published in the Professional Engineer in accordance with our Constitution and By-Laws. Case No. 18 was handled by your Chairman alone and finally disposed of by your Board, but as yet has not been published. Besides the above a considerable number of cases, not of general interest, were handled by your Chairman informally.

Obviously the problem facing the Association is a large one, and its work is beset with difficulties of many kinds. The danger of injustice to individuals is ever present, but the guiding principle of service, honest service based upon truth, can, in the hands of farsighted forceful men, be relied upon to lead on to a better understanding and to a sound conception of the duty of the engineer whether in public or in private practice.

\title{
Shall Corporations Be Authorized to Practise Engineering?
}

\author{
By William J. Wilgus \\ Consulting Engineer, New York City
}

GHOULD a corporation practise en$D$ gineering? The layman will perhaps at first thought reply in the affirmative, always with the provision, however, that the engineering service so rendered conforms with the best professional standards of practice; and yet the question is by no means so easily answered when considered from all sides and especially from the point of view of public expediency.

Is it not generally recognized that a corporation is organized and administered primarily for gain? We are not here speaking of that class of corporations which serve a philanthropic or charitable cause, but of the every-day business corporation, aggressively "on the make" as it were, and reaching out vigorously to increase its power and earning capacity. All such corporations of this latter class as are ably administered, strive to perform some economically useful service. Those wholly or partly engaged in engineering doubtless endeavor to furnish their clients or customers with engineering advice and skill consistent with the highest standards of the engineering profession. But considering the very nature of the corporation, is it possible to accomplish this purpose?

May we not draw this comparison between the purposes of a corporation and those of a profession? On the one hand, a profession is commonly regarded as, and may be defined as, a vocation having to do with the instructing, guiding and advising of others, or with serving them in some art, calling, vocation, or employment within the limitations not only of law but also of rules or standards known as a code of ethics. On the other hand, a typical engineering corporation is organized, and its work carried on, for the purpose 
of monetary gain. It functions, of course, within the limits proscribed by law but it is not a subscriber, speaking broadly, to any code of ethics, professional or otherwise. It acts as a corporate entity, and the liability of its individual owners is strictly limited. In a sense, it is an instrument, often with large financial responsibility, but without soul. Its policies are of necessity those dictated by expediency from its own self-interested standpoints; its object, dividends, and these as large as is consistent with sound commercial policy. It has been well said that "business has gain as its principal aim while a profession has service as its lode-star, with gain as a by-product."

\section{The Conflict of Interests}

An engineer retained by his client occupies the same relative position as the lawyer or doctor. His client's interests are his interests in so far as they are compatible with truth, ethics and scientific knowledge. His work is the solution of the engineering problems of the undertaking in such manner as to provide for his client, engineering skill, unbiased by self-interest and free from any outside influence or pressure which could be detrimental to his client.

Not so the corporation, with an engineering staff, highly skilled though it may be, financed by bankers and perhaps influenced and even controlled by manufacturers. Here we have many interests and often those of the engineering staff, ordinarily supposed to represent the client, that is to say, the public, are sadly subordinate. The manufacturers believe their products to be the best obtainable for the purposes of the "client." Why, then, should not the engineers which the corporation employs be requested to specify them? When we consider the position of the individuals composing the engineering staff of such a company we recognize at once the fact that there are two masters to be served. Is it remarkable that the interests of the client inevitably suffer under such conditions?

In view of the arguments thus far presented it seems fair to assume that no group of non-engineers can hope, under the guise of an engineering corporation, to offer engineering services without at least arousing suspicion as to their real purposes. It is emphatically not in the public interest for a corporation ostensibly to pose as a professional body when its allied or collateral interests are such as to influence its engineering judgment. Engineers with a full appreciation of the ethics of their profession, resent undue influence exerted upon them which will in any way hamper their freedom of action or of thought. It is therefore difficult to see how these engineering corporations are to provide themselves with the highest grade of engineering talent, or, indeed, with any engineers at all, except those who are willing to subject themselves and their work to the suspicion of improper influence on the part of their employers.

The following quotation from a letter addressed to the Governor of New York by a committee of leading engineers forcefully presents arguments against the licensing of corporations for the practice of engineering.

What is viewed by us with alarm is the sanctioning of a condition under which an engineering corporation may have bankers, manufacturers and contractors on its board who may so dominate its policy as to influence its management, including its engineering employes, in the preparation of reports, plans, contracts and specifications and in the supervision of work, in such manner as to favor the outside interests of such directors to the injury of the client (the public). This is no idle fear. In the case of common carriers this practice of interlocking directorates is forbidden by law. 
The professional engineer in the employ of an engineering corporation or unrestricted partnership, made up in whole or part of non-engineers, is relegated to a position of anonymity or that of the servant, relieving him of all professional responsibility to the client and placing him under the direction of those whose primary interest is a banker's or contractor's profit.

The professional engineer who signs a report or an engineering plan or specification is personally responsible. The engineer who works for an engineering corporation controlled by bankers or contractors is responsible only to the corporation upon which no equivalent responsibility is imposed by the State.

In a word, the engineering corporation, by which the engineer is employed or with which he is associated, is responsible only in a legal sense, and cannot be held for violations of a code of ethies to which it is not a subscriber.

The interposition of the impersonal corporation between the client and the professional engineer frees the latter from the responsibility for the unprofessional acts of his employer.

Corporations are free blatantly to advertise and to solicit patronage, while independent engineers are restrained from doing so either by good taste or by professional ethics. In fact there are well-known instances of practices by engineering corporations and unrestricted partnerships which are in direct violation of the professional ethics to which some of their officers or members in their individual capacities have subscribed. This is unfair to the independent engineer and destructive of that high respect for the profession which is of public concern.

It has been said that the public interest will be best promoted by recognizing by law the right of corporations to practice the profession of engineering, because the tendency of the times is in the direction of the performance of work by corporate aggregations of capital and brains not feasible in the case of the individual or independent engineer. This may perhaps be effectively answered by pointing to recent work of great magnitude performed under the direction of independent engineers, as follows:

1. Barge and ship canals, including terminals.

2. Catskill Water Supply.

3. Subway system of the City of New York.

4. Great tunnels and bridges.

5. Great railway terminals, including the Grand Central and Pennsylvania Railroad New York terminals.

6. Electrification of steam railroads, including the New York Central, Pennsylvania and Long Island railroads, with their collateral improvements.

7. Rehabilitation of great trunk lines for heavy motive power.

8. Vast system of highway improvements.

9. Port, railroad and other construction required for our Army at home and abroad.

A further answer to this statement lies in recent disclosures in the business world. Certainly it is not in the public interest to favor the interposition of ethicless-business between the professional engineer and the public.

It would be clearly wrong to restrict or hinder the employment in a professional capacity of engineers by corporations, but it is certainly not in accordance with engineering ethics for these corporations to offer the services of their employed engineers to the public; nor is it for the public good. The corporation composed entirely of engineers, all adhering to the recognized standards of professional ethics and without "entangling alliances," may be able to render effective service. There seems to be no adequate grounds, however, for the incorporation of such a body of engineers and there are strong reasons against it, chief of which, perhaps, is the suspicion rightly or wrongly attached by the public to any corporate body posing as professional and professing its allegiance to professional ideals. 